\title{
INVENTARISASI PERMUKIMAN DI KAWAWASAN SEMPADAN REL KERETA API KOTA PADANG PANJANG
}

\author{
Thomas Hendra Sitanggang \\ Program Studi Geografi \\ Fakulitas Ilmu Sosial Universitas Negeri Padang \\ e-mail: thomashendra3@gmail.com
}

\begin{abstract}
ABSTRAK
Penelitian ini bertujuan untuk mengetahui persebaran permukiman dan faktor pendorong masyarakat mendirikan permukiman di kawasan sempadan rel kereta api di Kota Padang Panjang.

Jenis penelitan menggunakan metode deskriptif kuantitatif. Populasi yang digunakan adalah seluruh bangunan yang berada di kawasan sempadan rel dengan jumlah sebesar 385 bangunan.

Hasil dari penelitian ini menunjukan bahwa 1) persebaran permukiman di kawasan sempadan rel kereta api tersebar di 11 kelurahan dengan jumlah dengan total luas permukiman sebesar $49.673 \mathrm{~m}^{2}$. Permukiman yang berada di kawasan sempadan rel berjumlah 385 bangunan. Kondisi permukiman di kawasan sempadan rel kereta api didominasi oleh bangunan permanen dengan rata-rata jarak dari rel kereta api sebesar 5 sampai 10 meter. Kondisi aksesibilitas permukiman di kawasan sempadan rel sudah cukup baik dengan didominasi jalan cor/beton dan jalan aspal. 2) Faktor pendorong tumbuhnya permukiman di kawasan sempadan rel dibagi kedalam tiga yakni aspek fisik, aspek sosial, dan aspek ekonomi. Aspek fisik yang menjadi faktor pendorong tumbuhnya permukiman di kawasan sempadan rel adalah tersedianya lahan untuk membangun permukiman. Aspek sosial yang menjadi faktor pendorong tumbuhnya permukiman di kawasan sempadan rel adalah tersedianya fasilitas-fasilitas pendukung di kawasan sempadan rel. Aspek ekonomi yang menjadi faktor pendorong tumbuhnya permukiman di kawasan

sempadan rel adalah harga sewa lahan murah menguntungkan masyarakat dari segi ekonomi.
\end{abstract}

Kata Kunci: inventarisasi, permukiman di sempadan rel, faktor pendorong permukiman

\section{ABSTRAC}

This study aims to determine the distribution of settlements and the factors driving the community to establish settlements in the railway border area in the city of Padang Panjang. Type of research using quantitative descriptive method. The population used is all buildings located in the rail area with a total of 385 buildings.

The results of this study show that 1) the ditribution of settlements in the railway border areas spread in 11 villages with the total of settlements by $49.673 \mathrm{~m}^{2}$. Settlements located in railway border amounted to 385 buildings. The condition of settlements in the railway border area is dominated by permanent buildings with an average distance from the railway line of 5 to 10 meters. The condition of the accessibility of settlements in the rail area is good enough with dominated concrete roads and asphalt roads. 2) The driving factors for the growth of settlements in the railway border are divided into three aspects, namely physical, social, and economic aspects. Physical aspect that becomes the driving factor for the growth of settlements in rail area is the availability of land to build settlements. The social aspect that is the driving factor for the growth of settlements in the railway area is the availability of supporting facilities in the rail area. The economic aspect that is the driving factor for the growth of settlements in the railway area is the cheap land rent rates benefit the community from the economic point.

Keywords: inventory, settlement in railway border, settlement driving factor

\footnotetext{
${ }^{1}$ Artikel ini ditulis dari skripsi penulis dengan judul Inventarisasi Permukiman di Kawasan Sempadan Rel Kereta Api Kota Padang Panjang untuk wisuda periode Maret 2018
} 


\section{PENDAHULUAN}

Permukiman adalah bagian dari lingkungan hunian yang terdiri atas lebih dari satu satuan perumahan yang mempunyai prasarana, sarana, utilitas umum, serta mempunyai penunjang kegiatan fungsi lain di kawasan perkotaan atau kawasan perdesaan. Pertambahan jumlah penduduk di daerah perkotaan mengakibatkan kebutuhan sarana dan prasarana

perkotaan semakin meningkat, pertambahan penduduk ini juga diiringi oleh adanya proses perpindahan penduduk ke kota. Tingginya laju

pertumbuhan penduduk dan perpindahan masyarakat ke kota dapat mengakibatkan kota semakin padat.

Peningkatan jumlah penduduk menyebabkan semakin tingginya kebutuhan perumahan dan jumlah permintaan lahan permukiman, yang pada akhirnya akan berdampak pada meningkatnya nilai suatu lahan permukiman.

Permintaan akan lahan yang semakin meningkat mengakibatkan

masyarakat banyak melakukan pembangunan kawasan permukiman di kawasan yang digunakan sebagai kawasan lindung dan kawasan rawan bencana. Pembangunan permukiman di kawasan lindung seperti kawasan sempadan juga banyak ditemukan di kota-kota besar. Salah satu kawasan lindung yang digunakan sebagai permukiman adalah kawasan sempadan rel kereta api. Penggunaan lahan di kawasan sempadan rel kereta api umumnya banyak digunakan sebagai permukiman dan sebagian lahan

pertanian. Dampak yang akan ditimbulkan jika memanfaatkan sempadan rel kereta api sebagai

permukiman antara lain yaitu terganggunya kelancaran transportasi kereta api selain itu kenyamanan permukiman akan terganggu oleh kebisingan dan bangunan rumah akan mengalami kerusakan akibat getaran yang diakibatkan oleh kereta api.

Penggunaan kawasan sempadan rel kereta api sebagai kawasan permukiman jelas akan mengganggu kelancaran transportasi kereta api. Transpotasi kereta api sangat dibutukan dalam mendukung pergerakan penduduk. Kota-kota besar di Pulau Jawa, transportasi kereta api sangat diminati oleh masyarakat karena sangat ekonomis. Di Pulau Sumatera transportasi kereta api masih belum terlalu diminati oleh masyarakat, kereta api hanya ada beroperasi di kota kota besar seperti Kota Medan dan Kota Padang. Di Provinsi Sumatera Barat, rel kereta api juga menghubungkan beberapa kota akan tetapi kereta api sudah tidak beroperasi lagi. Transpotasi kereta api di Sumatera Barat dahulu digunakan sebagai transportasi pengangkutan batu bara. Akibat tidak beroperasi lagi kereta api banyak kawasan disepanjang rel kereta api yang dimanfaatkan sebagai lahan permukiman baik legal maupun ilegal. Peraturan mengenai penggunaan lahan di sepanjang rel kereta api sudah ditetapkan pada Undang Undang Dasar Nomor 23 Tahun 2007 dan zonasi mengenai batas sempadan kereta api sudah ditetapkan pada Permen PU nomor 5 Tahun 2008 ( Permen PU nomor 5 Tahun 2008 Tentang Pedoman 
dan Pemanfaatan Ruang Terbuka Hijau

Di Kawasan Perkotaan).

Kota Padang Panjang merupakan salah satu kota yang dilalui jalur kereta api yang juga akan mulai dihidupkan kembali. Rel kereta api yang berada di Kota Padang Panjang masih ada dan hanya butuh direnovasi kembali. Kota

Padang Panjang juga sudah mengeluarkan peraturan daerah yang mengatur tentang garis sempadan rel kereta api yang tertera dalam Perda no 2 dan 4 tahun 2013. Jika dilihat dari peraturan perundang-undangan yang mengatur penggunaan lahan di sempadan kereta api, kawasan permukiman yang berada di sepanjang rel kereta api di Kota Padang Panjang sudah banyak yang melanggar. Hal ini terlihat dari masih banyaknya permukiman ataupun bangunan yang sangat dekat dengan rel kereta api.

Tabel 1. Luas Permukiman Kota Padang Panjang.

\begin{tabular}{|l|lr|l|}
\hline No & Permukiman & $\begin{array}{l}\text { Luas } \\
(\quad)\end{array}$ \\
\hline 1 & $\begin{array}{l}\text { Permukiman } \\
\text { sempadan rel } \\
\text { api }\end{array}$ & kereta & 49.673 \\
\hline 2 & $\begin{array}{l}\text { Luas } \\
\text { sempadan rel kereta } \\
\text { api }\end{array}$ & 331.105 \\
\hline
\end{tabular}

Sumber : RTRW Kota Padang Panjang tahun 2012-2032 dan perhitungan dari interprestasi Citra Quickbird Kota Padang Panjang tahun 2014.

Dari data diatas terlihat cukup banyak permukiman yang berdiri di sempadan rel kereta api. Banyaknya permukiman di sempadan rel kereta api Kota Padang Panjang membuat peneliti ingin menganalisis permukiman di sempadan rel kereta api yang terdapat di Kota Padang Panjang dan mengetahui faktor-faktor pendorong masyarakat dalam mendirikan bangunan di sempadan rel kereta api di Kota Padang Panjang.

Menurut PP No. 27 tahun 2014, inventarisasi adalah kegiatan untuk melakukan pendataan, pencatatan, dan pelaporan hasil pendataan barang milik negara / daerah. Dari beberapa pengertian tersebut dapat disimpulkan bahwa inventarisasi aset merupakan serangkaian kegiatan untuk melakukan pencatatan, pengamanan, pendokumentasian \& pelaporan hasil pencatatan kepemilikan suatu aset. Berdasarkan Peraturan Pemerintah Republik Indonesia Nomor 27 tahun 2014 pasal 85 ayat 1 menyebutkan bahwa pengguna barang melakukan inventarisasi barang milik negara/daerah paling sedikit 1(satu) kali dalam 5 (lima) tahun. Hal tersebut dilakukan agar aset yang ada di suatu instansi pemerintah dapat dikontrol

dengan baik sehingga bisa meminimalisir masalah yang muncul akibat aset yang tidak tercatat dan penggunaan aset yang tidak sesuai dengan tupoksi dapat segera dihentikan.

Permukiman merupakan suatu kesatuan wilayah di mana suatu perumahan berada, sehingga lokasi dan lingkungan perumahan tersebut sebenarnya tidak akan pernah dapat lepas dari permasalahan dan lingkup keberadaan suatu permukiman. Oleh karena itu sebaiknya jika akan dilakukan pengembangan perumahan, terlebih dahulu harus betul-betul 
diketahui dan diteliti keadaan dan kondisi permukiman diman perumahan akan dibangun. Upaya tersebut antaralain bisa dilakukan melalui studi kelayakan terlebih dahulu agar keberadaan perumahan tersebut dapat betul-betul sesuai dengan kebutuhan

yang semestinya dan dalam operasionalnya nanti dapat mendukung arah dan laju pengembangan permukiman yang sudah direncanakan(Suparno dan Endy, 2005).

Dalam kaitannya dengan persebaran penduduk dengan tumbuhnya perumahan dan permukiman baik di perkotaan maupun di perdesaan yang relatif datar akan membentuk polapola tersendiri yang secara keseluruhan dipengaruhi oleh posisinya secara geografis dan karakteristik tempatnya (Branch dalam Yoelianto, 2005). Hal ini mencerminkan bahwa kondisi topografi yang relatif datar di wilayah penelitian merupakan mo Dalam perkembangan perumahan ada 3 (tiga) faktor yang berpengaruh. Faktor-faktor tersebut antara lain: (1) Kependudukan; (2) Pertanahan; (3)

Pembiayaan dan Dana(Peraturan Perundang-undangan Departemen Pekerjaan Umum, 1994). Selama kebijaksanaan tentang lokasi perumahan belum ditegakkan secara mapan. Maka perkembangan lokasi perumahan, termasuk sarana dan prasarananya akan cenderung berjalan masing-masing tanpa keterpaduan yang harmonis dengan elemen lainnya. Dengan bermunculannya pengembang yang semakin banyak, telah mendorong perkembangan lokasi-lokasi perumahan baru tumbuh secara acak.
Dalam Kamus Bahasa Indonesia, internal menyangkut bagian dalam (tubuh, diri, mobil). Jadi dapat diasumsikan faktor innternal dalam

memilih lokasi tempat tinggal merupakan faktor yang berasal dari dalam diri seseorang tersebut untuk bertempat tinggal disuatu tempat.

Selanjutnya eksternal artinya menyangkut bagian luar. Jadi, dapat di asumsikan faktor eksternal dalam

memilih lokasi tempat tinggal merupakan faktor yang berasal dai luar diri seseorang untuk bertempat tinggal pada suatu tempat.

Perkeretaapian adalah satu kesatuan sistem yang terdiri atas prasarana, sarana, dan sumber daya manusia, serta norma, kriteria, persyaratan, dan prosedur untuk penyelenggaraan transportasi kereta api (UU No.23, 2007). Perkeretaapian merupakan angkutan yang ramah lingkungan, dengan emisi gas buang kecil dan pengembangan teknologi

kereta berbasis energi listrik, memungkinan sebagai moda angkutan yang mampu menjawab masalah lingkungan hidup manusia di masa yang akan datang. Dapat dipergunakan sebagai pelayanan aktifitas khusus, karena daya angkut besar, dan memiliki jalur sendiri, sehingga perjalanan suatu aktifitas khusus dilaksanakan tanpa banyak memberi dampak sosial. Kereta api adalah sarana perkeretaapian dengan tenaga gerak, baik berjalan sendiri maupun dirangkaikan dengan sarana perkeretaapian lainnya, yang akan ataupun sedang bergerak di jalan rel yang terkait dengan perjalanan kereta api. 
Jalan kereta api, yaitu jalur yang terdiri atas rangkaian petak jalan rel dimana jalan rel adalah satu kesatuan konstruksi yang terbuat dari baja, beton, atau konstruksi lain yang terletak di permukaan, di bawah, dan di atas tanah atau bergantung beserta perangkatnya. Fungsinya untuk mengarahkan jalannya kereta api, yang meliputi ruang manfaat jalur kereta api, ruang milik jalur kereta api, dan ruang pengawasan jalur kereta api, termasuk bagian atas dan bawahnya yang di peruntukkan bagi lalulintas kereta api seperti jembatan, bangunan hikmat untuk drainase, underpass dan flyover dan terowongan ( UU

No.13Tahun1992). Secara umum komponen penyusun jalan rel sebagai berikut :
a. $\operatorname{Rel}($ rail $)$
b. Penambat(fastening system)
c. Bantalan(sleeper)
d. Lapisan pondasi atas atau lapisan balas(ballast)

e. Lapisan pondasi bawah atau lapisan subbalas(subballast)

f. Lapisan tanah dasar(subgrade)

Garis sempadan adalah garis batas luar pengaman yang ditetapkan dalam mendirikan bangunan dan atau pagar yang ditarik pada jarak tertentu sejajar dengan as jalan, tepi luar kepala jembatan, tepi sungai, tepi saluran, kaki tanggul, tepi situ/rawa, tepi waduk, tepi mata air, as rel kereta api, jaringan tenaga listrik dan pipa gas, tergantung jenis garis sempadan yang dicantumkan. Di bagian luar dari garis ini, pemilik tanah tidak diperkenankan untuk mendirikan bangunan. Daerah sempadan adalah kawasan sepanjang jalan, sungai, saluran, danau/waduk, mata air, rel kereta api, jaringan listrik tegangan tinggi yang dibatasi kanan/kirinya dengan garis sempadan.

Pada Permen PU No
5/PRT/M/2008 tentang pedoman
penyediaan dan pemanfaatan ruang
terbuka hijau di kawasan perkotaan
dijelaskan dengan tegas untuk menetukan lebar garis sempadan jalan kereta api di kawasan perkotaan.Kriteria garis sempadan jalan kereta api yang dapat digunakan untuk RTH adalah sebagai berikut:

a. Garis sempadan jalan rel kereta api adalah ditetapkan dari as jalan rel terdekat apabila jalan rel kereta api itu lurus.

b. Garis sempadan jalan rel kereta api yang terletak di tanah timbunan diukur dari kaki tanggul.

c. Garis sempadan jalan rel kereta api yang terletak di dalam galian, diukur dari puncak galian tanah atau atas serongan.

d. Garis sempadan jalan rel kereta api yang terletak pada tanah datar diukur dari as jalan rel kereta api.

e. Garis sempadan jalan rel kereta api pada belokan adalah lebih dari 23 meter diukur dari lengkung dalam sampai as jalan. Dalam peralihan jalan lurus ke jalan lengkung diluar as jalan harus ada jalur tanah yang bebas, yang secara berangsur-angsur melebar dari jarak lebih dari 11 sampai lebih dari $23 \mathrm{~m}$. Pelebaran tersebut dimulai dalam jarak $20 \mathrm{~m}$ di muka lengkungan untuk selanjutnya menyempit lagi sampai jarak lebih dari 11 meter.

f. Garis sempadan jalan rel kereta api sebagaimana dimaksud tidak berlaku 
apabila jalan rel kereta api terletak di tanah galian yang dalamnya 3,5 meter.

g. Garis sempadan jalan perlintasan sebidang antara jalan rel kereta api dengan jalan raya adalah $30 \mathrm{~m}$ dari as jalan rel kereta api pada titik perpotongan as jalan rel kereta api dengan as jalan raya dan secara berangsur-angsur menuju pada jarak lebih dari $11 \mathrm{~m}$ dari as jalan rel kereta api pada titik $600 \mathrm{~m}$ dari titik perpotongan as jalan kereta api dengan as jalan raya.

Peraturan Permen PU No
5/PRT/M/2008 tentang pedoman
penyediaan dan pemanfaatan ruang
terbuka hijau di kawasan perkotaan
dapat diuraikan pada tabel berikut:

Tabel 2. Lebar Garis Sempadan Rel Kereta Api.

\begin{tabular}{|c|c|c|}
\hline Jalan rel & Objek & \\
\hline $\begin{array}{ll}\text { kereta } & \text { api } \\
\text { terletak di }\end{array}$ & Tanaman & Bangunan \\
\hline $\begin{array}{lr}\text { a.Jalan } & \text { rel } \\
\text { kereta } & \text { api } \\
\text { lurus } & \end{array}$ & $>11 \mathrm{~m}$ & $>20 \mathrm{~m}$ \\
\hline $\begin{array}{l}\text { b.Jalan rel } \\
\text { kereta api } \\
\text { belokan/lengk } \\
\text { ungan } \\
\text { - lengkung } \\
\text { dalam } \\
\text { - lengkung } \\
\text { luar }\end{array}$ & $\begin{array}{l}>23 \mathrm{~m} \\
>11 \mathrm{~m}\end{array}$ & $\begin{array}{l}>23 \mathrm{~m} \\
>11 \mathrm{~m}\end{array}$ \\
\hline
\end{tabular}

Sumber: Permen PU No 5 Tahun 2008

Perda nomor 2 Tahun 2013 dan Perda no 4 Tahun 2013, Kota Padang

Panjang menetapakan peraturan mengenai penggunaan lahan di sepanjang sempadan kereta api di Kota Padang Panjang juga menetapkan jarak garis sempadan kereta api yaitu sejauh
20 meter dari as rel untuk jalur lurus serta 23 meter jalur lengkung dalam dan 11 meter untuk jalur lengkung luar.Peraturan daerah ini bahkan sudah dipasang di beberapa tempat di sepanjang rel kereta api. Pemasangan peraturan ini menandakan bahwa kawasan sempadan kereta api sangat berperan penting dalam mendukung kelancaran transportasi kereta api.

Berdasarkan kajian teori yang telah dijabarkan sebelumnya maka kerangka koseptual dalan penelitian ini adalah sebagai berikut:

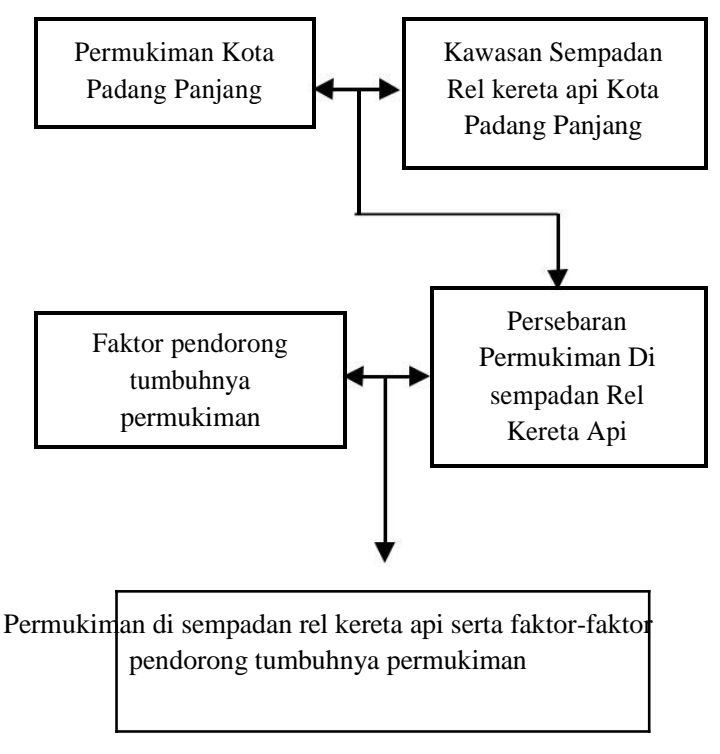

Gambar 1. Kerangka konseptual.

\section{METODE PENELITIAN}

Jenis penelitian pada penelitian ini adalah penelitian deskriptif kuantitatif. Penelitian deskriptif adalah suatu metode penelitian yang ditujukan untuk mengambarkan fenomena-fenomena yang ada yang berlangsung pada saat ini atau saat yang lampau. Populasi yang digunakan pada penelitian ini adalah seluruh permukiman atau rumah yang berada di sempadan rel kereta api di 
Kota Padang Panjang. Jumlah populasi pada peneltian ini adalah sebesar 385 bangunan.

Jenis data yang digunakan yaitu data primer dan data sekunder, data sekunder lebih banyak diperlukan dalam penelitian ini. Data primer dapat berupa hasil observasi dan data angket atau kuesioner di lapangan digunakan untuk melihat kondisi serta faktor pendorong tumbuhnya permukiman di kawasan sempadan rel kereta api. Data sekunder cukup banyak diperlukan dalam penelitian ini yaitu citra Kota Padang Panjang, peta-peta dasar seperti peta administrasi, peta jaringan rel kereta api dan peta lainya yang mendukung dalam penelitian ini. Pengumpulan data yang dilakukan dalam penelitian ini yaitu melalui tahapan pengolahan data primer dan sekunder serta wawancara dan

pengisisan kuesioner. Tahapan penelitian dapat diuraikan sebagai berikut:

1. Tahap persiapan

2. Tahap pembuatan peta kawasan sempadan rel kereta api.

3. Tahap pengolahan citra Kota Padang Panjang

4. Tahap observasi lapangan

5. Tahap penyelesaian

Teknik analisis data dalam peneltian ini dapat dibagi kedalam dua analisis yakni sebagai berikut:

1. Analisis persebaran permukiman yang berdiri di sempadan rel kereta api di Kota Padang Panjang.

2. Analisisfaktorpendorong masyarakat dalam mendirikan permukiman di sempadan rel kereta api di Kota Padang Panjang.

\section{HASIL DAN PEMBAHASAN}

Pesebaran permukiman di kawasan sempadan rel kereta api Kota Padang Panjang dapat diuraikan pada tabel sebagai berikut:

Tabel 3. Permukiman di kawasan sempadan rel kereta api Kota Padang Panjang.

\begin{tabular}{|l|l|r|r|}
\hline \multirow{2}{*}{ No } & \multirow{2}{*}{ Kelurahan } & \multicolumn{2}{|c|}{$\begin{array}{c}\text { Permukiman di } \\
\text { sempadan rel }\end{array}$} \\
\cline { 3 - 4 } & & \multicolumn{1}{|c|}{ Luas } & \multicolumn{1}{|c|}{ Jumlah } \\
\hline 1 & Balai balai & $5.295 \mathrm{~m}^{2}$ & 45 \\
\hline 2 & Ekor lubuk & $7.018 \mathrm{~m}^{2}$ & 28 \\
\hline 3 & $\begin{array}{l}\text { Guguk } \\
\text { malintang }\end{array}$ & $883 \mathrm{~m}^{2}$ & 6 \\
\hline 4 & $\begin{array}{l}\text { Kampung } \\
\text { manggis }\end{array}$ & $3.632 \mathrm{~m}^{2}$ & 29 \\
\hline 5 & $\begin{array}{l}\text { Koto } \\
\text { panjang }\end{array}$ & $3.628 \mathrm{~m}^{2}$ & 31 \\
\hline 6 & Ngalau & $7.121 \mathrm{~m}^{2}$ & 62 \\
\hline 7 & Pasar using & $1.618 \mathrm{~m}^{2}$ & 10 \\
\hline 8 & Sigando & $4.969 \mathrm{~m}^{2}$ & 26 \\
\hline 9 & $\begin{array}{l}\text { Silaing } \\
\text { atas }\end{array}$ & $9.070 \mathrm{~m}^{2}$ & 95 \\
\hline 10 & $\begin{array}{l}\text { Tanah } \\
\text { hitam }\end{array}$ & $1.987 \mathrm{~m}^{2}$ & 20 \\
\hline 11 & $\begin{array}{l}\text { Tanah pak } \\
\text { lambik }\end{array}$ & $4.452 \mathrm{~m}^{2}$ & 33 \\
\hline Jumlah & $\mathbf{4 9 . 6 7 3}$ & $\mathbf{3 8 5}$ \\
\hline
\end{tabular}

Sumber: Pengolahan citra Quickbird tahun 2014 dan RTRW 2012-2032 Kota Padang Panjang.

Berdasarkan tabel diatas dapat diuraikan bahwasanya permukiman yang berdiri di kawasan sempadan rel kereta api tersebar di 11 kelurahan dari total 16 kelurahan yang ada di Kota Padang Panjang. Total luas permukiman 
yang berada di kawasan sempadan rel kereta api adalah sebesar $49.673 \mathrm{~m}^{2}$. Luas ini merupakan jumlah yang cukup kecil jika dibandingkan dengan luas kawasan sempadan rel kereta api di Kota Padang Panjang. Permukiman di kawasan sempadan rel kereta api tersebar dari wilayah tengah sampai timur kota Padang Panjang. Wilayah bagian barat Kota Padang Panjang tidak perdapat permukiman dikarenakan wilayah bagian barat Kota Padang Panjang merupakan kawasan lindung dan dilarang untuk mendirikan permukiman.

Berdasarkan tabel diatas juga dapat diketahui jumlah bangunan permukiman yang berada di kawasan sempadan rel kereta api di Kota Padang Panjang sebanyak 385 bangunan. Bangunan-bangunan ini sendiri terdiri dari rumah-rumah serta fasilitas-fasilitas umum. Jumlah bangunan-bangunan di sempadan rel kereta api ini nantinya akan semakin bertambah jika tidak adanya pengendalian dari pemerintah dan PT KAI dalam mengelola lahan di sepanjang rel kereta api.

Kondisi permukiman di kawasan sempadan rel kereta api Kota Padang Panjang berdasarkan hasil penelitian dapat dibagi dalam kriteria berikut:

a. Jenis bangunan

Jenis bangunan di kawasan sempadan rel didominasi oleh

rumah-rumah permanen atau berdinding tembok. Rumah permanen yang berada di kawasan sempadan rel cukup beresiko jika adanya pembongkaran rumah yang berada terlalu dekat dekat dengan rel kereta api. b. Jarak rumah dari rel

Jarak rumah dari rel yang berada di kawasan sempadan rel kereta api Kota Padang Panjang didominasi jarak 5 sampai 10 meter. Jarak tersebut sudah jelas melanggar ketentuan jarak rumah/bangunan dengan rel kereta api dan jika ada program pembongkaran dari pemerintah maka akan banyak rumah yang akan dibongkar.

c. Akses jalan menuju rumah

Akses jalan menuju permukiman dominasi oleh jalan cor/beton dan jalan aspal. Hal ini menunjukan bahwa kondisi infrastruktur di kawasan sempadan rel kereta api sudah baik.

d. Kondisi fasilitas umum

Kondisi fasilitas umum yang mendukung masyarakat di kawasan sempadan rel kereta api dapat dikatakan cukup memadai. Fasilitas umum yang mendukung permukiman di sempadan rel Kota Padang Panjang yaitu fasilitas pendidikan didominasi, fasilitas kesehatan, fasilitas peribadatatan, serta fasilitas perdagangan. Dari beberapa fasilitas umum diatas dapat dikatakan fasilitas umum tersebut mendukung masyarakat yang berada di kawasan sempadan rel dan menjadi salah satu daya tarik masyarakat dalam mendirikan permukiman di kawasan tersebut.

Persebaran permukiman di sempadan rel kereta api Kota Padang Panjang dapat dilihat pada peta sebagai berikut: 


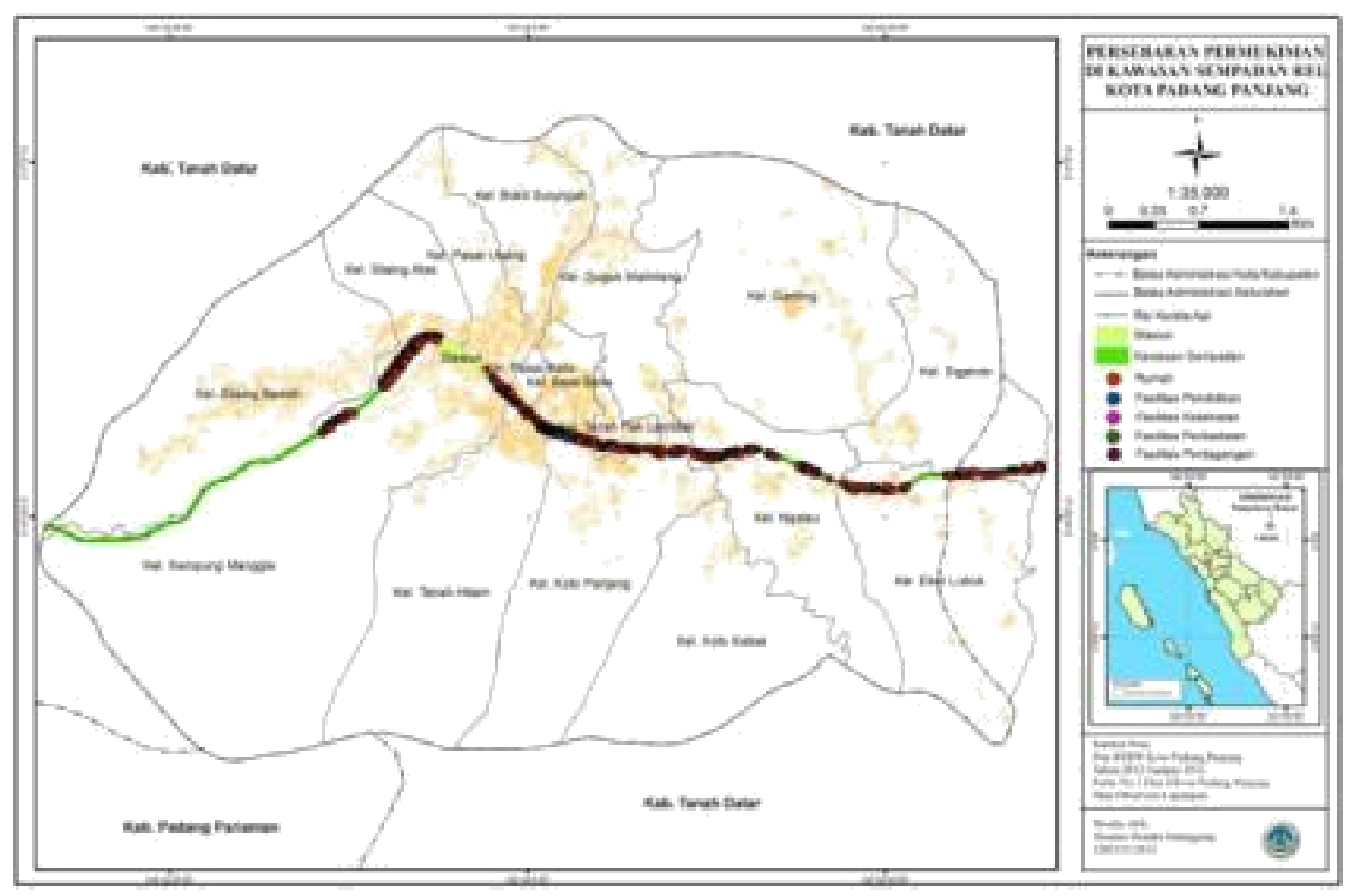

Gambar 2. Peta persebaran permukiman di kawasan sempadan rel kereta api Kota Padang Panjang

Berdasarkan peta diatas dapat dilihat persebaran permukiman yang berada di kawasan sempadan rel kereta api di Kota Padang Panjang. Permukiman tersebar memanjang dari tengah hingga timur Kota Padang Panjang. Persebaran permukiman dibagi kedalam persebaran rumah, fasilitas pendidikan, fasilitas kesehatan, fasilitas peribadatan, dan fasilitas perdagangan yang berada di kawasan sempadan rel kereta api Kota Padang Panjang. Rumah memiliki jumlah yang paling banyak tersebar di kawasan sempadan rel kereta api di Kota Padang Panjang. Jumlah rumah yang banyak tersebar di kawasan sempadan rel serta fasilitas yang berada di kawasan

sempadan rel nantinya akan mempengaruhi transportasi kereta api saaat mulai beroperasi kembali di Kota Padang Panjang.
Permukiman yang berada di kawasan sempadan rel kereta api di Kota Padang Panjang tersebar pada bagian tengah hingga timur wilayah Kota Padang Panjang. Banyaknya permukiman yang tumbuh di bagian tengah kota dipengaruhi oleh arah

pembangunan permukiman lebih bertumbuh di bagian pusat kota dimana banyaknya fasilitas-fasilitas umum di wilayah tersebut. Bagian barat Kota Padang Panjang tidak ditemukan permukiman di kawasan sempadan rel disebabkan oleh wilayah bagian barat kota merupakan kawasan lindung yang jelas dilarang membangun permukiman. Permukiman dibagian timur Kota Padang Panjang memiliki pola yang cenderung menyebar. Pola ini dipengaruhi oleh banyaknya lahan pertanian yang berada di bagian timur dari Kota Padang Panjang. 
Berdasarkan kajian teori yang telah dijelaskan, ada tiga aspek yang menjadi faktor dalam mendirikan permukiman sebagai berikut:

a. Aspek fisik

Aspek fisik yang mendorong masyarakat mendirikan permukiman di kawasan sempadan rel kereta api di Kota Padang Panjang dapat diuraikan sebagai berikut:

1) Tersedianya lahan/tanah yang digunakan sebagai lahan permukiman di sempadan rel kereta api di Kota Padang Panjang. Lahan/tanah di kawasan sempadan rel.

2) Tersedianya sumber air bersih di permukiman di sempadan rel Kota Padang Panjang. Sumber air bersih permukiman di kawasan sempadan rel di Kota Padang Panjang bersumber dari mata air dan PDAM Kota Padang Panjang.

3) Tersedia sarana dan prasarana pendukung permukiman di kawasan sempadan rel kereta api di Kota Padang Panjang. Berdasarkan pengolahan data dan dokumentasi penelitian sudah diuraikan kondisi prasarana yang mendukung permukiman di kawasan sempadan rel Kota Padang Panjang sudah sangat mendukung.

Berdasarkan tiga indikator diatas, aspek fisik yang berada di kawasan sempadan rel kereta api di Kota Padang Panjang sudah mendukung dalam mendirikan permukiman.

b. Aspek sosial

Aspek sosial di kawasan sempadan rel kereta api sudah mendukung masyarakat dalam mendirikan permukiman di kawasan sempadan rel di Kota Padang Panjang. Aspek sosial yang berada di kawasan sempadan rel kereta api Kota Padang dapat diuraikan sebagai berikut:

1) Fasilitas pendidikan yang mendukung masyarakat di kawasan sempadan rel Kota Padang Panjang sudah dapat dikatakan mendukung. Jarak fasilitas pendidikan dengan permukiman di kawasan sempadan rel kereta api di Kota Padang Panjang rata-rata bejarak kurang dari 0,5 kilometer.

2) Fasilitas kesehatan yang mendukung masyarakat di kawasan sempadan rel kereta api diKota Padang Panjang didominasi oleh bidan. Jarak rata-ratafasilitaskesehatan dengan kawasan sempadan rel sebesar kurang dari 1 kilometer.

3) Fasilitas peribadatan yang mendukung masyarakat di kawasan sempadan rel kereta di Kota Padang Panjang didominasi musahala. Banyaknya fasilitas mushala karena masyarakat Kota Padang Panjangmayoritas beragama Islam.

4) Fasilitas perdagangan permukiman di kawasan sempadan rel kereta api sudah 
mendukung permukiman dengan jarak yang cukup dekat dari permukiman yakni kurang dari 0,5 kilometer.

Berdasarkan indikator diatas, aspek sosial yang berada di kawasan permukiman di kawasan sempadan rel kereta api Kota Padang Panjang sudah mendukung masyarakat dalam mendirikan permukiman di kawasan sempadan rel kereta api di Kota Padang Panjang.

c. Aspek ekonomi.

Aspek ekonomi masyarakat di kawasan sempadan rel kota Padang Panjang menunjukan tingkat kemampuan masyarakat dalam memiliki suatu lahan dan keuntungan dari segi lahan di kawasan sempadan rel kereta api di Kota Padang Panjang. Aspek ekonomi di kawasan sempadan rel kereta api di Kota Padang Panjang dapat diuraikan sebagai berikut:

1) Status kepemilikan lahan permukiman di kawasan sempadan rel di Kota Padang Panjang di dominasi oleh lahan/tanah sewa.

2) Harga sewa lahan/tanah di kawasan sempadan rel kereta api di Kota Padang Panjang bisa dikatakan lebih murah jika dibandingkan dengan harga sewa/lahan di daerah lain.

3) Kondisi harga sewa lahan yang murah menguntungkan masyarakat dalam segi ekonomi masyarakat di kawasan sempadan rel kereta api di Kota Padang Panjang.
Beradasarkan indikator diatas, aspek ekonomi yang mendorong

masyarakat dalam mendirikan permukiman di kawasan sempadan rel kereta api di Kota Padang Panjang yaitu harga sewa lahan murah menguntungkan masyarakat dari segi ekonomi.

Tiga aspek pendorong diatas menjadi faktor pendorong masyarakat dalam mendirikan permukiman di kawasan sempadan rel Kota Padang Panjang. Tiga aspek tersebut diambil beradasarkan kajian teori yang telah di uraikan pada bab sebelumnya. Berdasarkan uraian diatas ketiga aspek tersebut sudah mendukung masyarakat dalam mendirikan permukiman di kawasan sempadan rel kereta api di Kota Padang Panjang. Aspek pendorong tumbuhnya permukiman mengakibatkan adanya permukiman di kawasan sempadan rel kereta api di Kota Padang Panjang. Permukiman yang berada di kawasan sempadan rel jelas akan mengganggu aktifitas transportasi kereta api seandainya beraktifitas kembali di Kota Padang Panjang.

\section{PENUTUP}

\section{Kesimpulan}

Persebaran permukiman di kawasan sempadan rel kereta api Kota Padang Panjang berada di 11 kelurahan dari 16 kelurahan dengan total luas yaitu sebesar $49.673 \mathrm{~m}^{2}$. Permukiman yang berada di kawasan sempadan rel kereta api berjumlah 385 bangunan, terdiri dari 374 rumah hunian, 7 fasilitas pendidikan, 1 fasilitas kesehatan, 1 fasilitas perdagangan, 1 fasilitas peribadatan, dan 1 fasilitas pendukung. 
Kondisi permukiman di kawasan sempadan rel kereta api Kota Padang Panjang didominasi oleh bangunan permanen atau berdinding tembok dengan rata-rata jarak dari rel kereta api sebesar 5 sampai 10 meter. Kondisi aksesibilitas permukiman di kawasan sempadan rel kereta api dapat dikatakan baik dengan didominasi jalan cor/beton dan jalan aspal.

Faktor pendorong tumbuhnya permukiman di kawasan sempadan rel dibagi kedalam tiga yaitu aspek fisik, aspek sosial, dan aspek ekonomi. Aspek fisik yang menjadi faktor pendorong tumbuhnya permukiman di kawasan sempadan rel adalah tersedianya lahan untuk membangun permukiman. Aspek sosial yang menjadi faktor pendorong tumbuhnya permukiman di kawasan sempadan rel adalah tersedianya fasilitas-fasilitas pendukung di kawasan sempadan rel. Aspek ekonomi yang menjadi faktor pendorong tumbuhnya permukiman di kawasan sempadan rel adalah banyaknya lahan yang di sewa oleh masyarakat melalui PT KAI dengan harga yang lebih murah. Aspekaspek pendorong tumbuhnya permukiman di kawasan sempadan rel mengakibatkan adanya permukiman di kawasan sempadan rel kereta api di Kota Padang Panjang.

\section{Saran}

Pemerintah Kota Padang Panjang dan PT KAI (Kereta Api Indonesia) di Padang Panjang harus saling bekerjasama dalam pengaturan dan pengawasan permukiman di kawasan sempadan rel kereta api, sehingga masyarakat mengetahui ketentuan- ketentuan sebelum memilih lokasi

berkumim di sekitar rel kereta api.

Masyarakat diharapkan lebih bijak dalam memilih lokasi permukiman sebelum menentukan untuk tinggal di sekitar rel kereta api.

Masyarakat yang bermukim di kawasan sempadan rel kereta api Kota Padang Panjang harus mengelola lahan di sempadan rel kereta api dengan sebaik-baiknya apalagi dengan adanya rencana pengaktifan kembali transportasi kereta api di Kota Padang Panjang.

\section{DAFTAR PUSTAKA}

Departemen Pekerjaan Umum, Direktorat Jenderal Penataan Ruang. 2007,Undang-UndangUndang Republik Indonesia No

26 Tahun 2007.Tentang

Penataan Ruang.

Departemen Pekerjaan Umum, Direktorat Jenderal Penataan Ruang. 2008, Undang-UndangUndang Republik Indonesia. No 5 Tahun 2008. Tentang Pedoman dan Pemanfaatan Ruang Terbuka Hijau Di Kawasan Perkotaan.

Kota Padang Panjang. 2013. Peraturan Daerah Kota Padang Panjang No. 2 Tahun 2013. Tentang Sempadan Rel Kereta Api.

Kota Padang Panjang. 2013. Peraturan Daerah Kota Padang Panjang No. 4 Tahun 2013. Tentang Sempadan Rel Kereta Api.

M, Suparno Sastra Dan Endy Marlina.

2005. Perencanaan Dan Pengembangan Perumahan. Yogyakarta : Penerbit Andi.

Republik Indonesia. 1992. UndangUndang No. 13 Tahun 1992. Tentang Perkeretaapian. 
Republik Indonesia. 2007. Undang-

Undang No. 23 Tahun 2007.

Tentang Perkeretaapian.

Republik Indonesia. 2011. UndangUndang No. 1 Tahun 2011.

TentangPerumahan dan

Kawasan Permukiman.

Republik

Indonesia.

2014.

Peraturan

Pemerintah No 27 Tahun 2014.

TentangPengelolaan Barang

Milik Negara/Daerah. 